\title{
Birth body length, birth body weight and birth head circumference in neonates born in a single centre between 2011 and 2016
}

\author{
Beata Pawlus ${ }^{1}$, Andrzej Wiśniewski ${ }^{2}$, Paweł Kubik ${ }^{1}$, Katarzyna Milde ${ }^{3}$, \\ Leszek Gmyrek ${ }^{1}$, Ewa Pęsko' \\ ${ }^{1}$ Holy Family Specialist Hospital of the Independent Public Complex of Health Care Facilities in Warsaw, Poland \\ ${ }^{2}$ Józef Piłsudski University of Physical Education in Warsaw, Poland \\ ${ }^{3}$ Department of Biomedical Sciences, Section of Biometry, Józef Piłsudski University of Physical Education in Warsaw, Poland
}

\begin{abstract}
Objectives: Access to updated and accurate standards for local populations is important for the interpretation of body measurements in neonates and may have an impact on the doctor's recommendations for monitoring early childhood development.

Study aim: to present individual mean values for the most prevalent body measurements (i.e. birth body length (BBL), birth body weight (BBW) and birth head circumference $(\mathrm{BHC})$ ) in neonates and compare them to the duration of pregnancy.

Material and methods: The measurements (BBL, BBW and BHC) were collected and analyzed from over 27,000 neonates born in a single center. All women with single pregnancies with gestation ranging from 33 to 42 weeks were included in the study. Results: Mean values and statistically significant standard deviation values from population standards of BBL, BBW, and $\mathrm{BHC}$ were evaluated for neonates that were born between the $33^{\text {rd }}$ and $42^{\text {nd }}$ week of gestation. Analysis was conducted for the lower limit ( $10^{\text {th }}$ percentile), average ( $50^{\text {th }}$ percentile) and upper limit ( $90^{\text {th }}$ percentile).

Conclusions: This was the first time in Polish literature when population standards were presented for three body measurements of neonates. With the size of the cohort, these standards can be successfully implemented into routine clinical practice, especially for screening children with body size deficits.
\end{abstract}

Key words: reference standards for neonates, body length, birth weight, birth head circumference

Ginekologia Polska 2017; 88, 11:599-605

\section{INTRODUCTION}

For over a hundred years, the results of newborn body measurements have been used to evaluate their growth status at birth. Similarly, the increase in body length, later expressed as body height, is claimed to be less sensitive due to negative environmental impacts when compared to body weight [1]. Initially, the evaluation of growth status at birth was based only on the results of birth body length (BBL). Birth body weight (BBW) began to be measured after popular findings from Arvo Ylppö, starting in the 1930's [2]. Simplicity of BBW measurements and popularization of using scales for neonates led to the undeserved underestimation of the BBL measurements. The importance of BBL measurements in the clinical context started to be emphasized after Baker et al. proposed a concept that demonstrated the relationships between the presence of certain chronic conditions in adults and fetal growth rate (fetal programming, thrifty phenotype, developmental origins of health and disease). In the same period, research on the physical development of children born with body size deficits (neonates who were too short or underweight with respect to the duration of pregnancy) also became more extensive [3-11]. Since that time, body measurements at birth have been made with the emphasis on referencing birth body length to population standards and are now approached more often as a screening tool used for children with an ele- 
vated risk of growth disturbances and non-communicable diseases (NCDs) [12-14]. Therefore, formulation of specific recommendations for further care for neonates and children in their first months and years of life, especially, careful monitoring of growth and avoiding overfeeding, depends on the adequate and accurate body measurements at birth. Measurements should not only be made according to specific methodology but more importantly should be routinely completed with referencing the results to population standards $[15,16]$. It should be emphasized that evaluation of the status based only on raw measurements of several body dimensions, or in many instances only birth body weight, is now considered insufficient and incomplete. Ideally, they should be expressed in SDS (Standard Deviation Score) units, which provide a more accurate insight into the child's body size with respect to a population rather than standard growth charts. The benefits of using SDS units are especially pronounced in children with at least one body measurement below the 10th or over 90 th percentile. In such cases, accurate determination of the degree of deficit or excess in percentile terms is much more difficult.

Another important problem is choosing an adequate system of reference for evaluation of body size in neonates. This issue has been extensively explored in literature for many years and the universal standards for body size of neonates at birth (World Health Organization, WHO) substantially contributed to the increased number of publications on creating and using population standards $[17,18]$. Despite the routine use of growth standards in clinical practice proposed by WHO, many researchers have emphasized the benefits of the additional use of regional standards for body size of infants born locally in a specific region (neonates born "here and now") [19, 20]. It should be emphasized that no compilation of birth standards has been presented in Polish references concerning all three birth body measurements: birth body length (BBL), birth body weight (BBW) and birth head circumference (BHC). The lack of such standards weakens the quality of the evaluation of children's growth pattern.

\section{OBJECTIVES}

The aim of the study was to present individual mean values for the most prevalent body measurements (i.e. birth body length (BBL), birth body weight (BBW) and birth head circumference $(\mathrm{BHC})$ ) in neonates and compare them to the duration of pregnancy.

\section{MATERIAL AND METHODS}

The focus of the analysis was on the data concerning birth body length (BBL, $\mathrm{Cm}$ ), birth body weight (BBW, g), and birth head circumference $(\mathrm{BHC}, \mathrm{cm})$ in a cohort of children born between $1^{\text {st }}$ January 2011 to $31^{\text {st }}$ December 2016 in a single center; Maternity Department of the Holy Family Specialist Hospital of the Independent Public Complex of Health Care Facilities in Warsaw. All women with single pregnancies with gestation ranging from 33 to 42 weeks were included in the study. Although all the neonates were born in a hospital located in one of Warsaw's central districts (Mokotów), their parents lived in various regions of the Masovia Province in Poland.

$\mathrm{BBW}, \mathrm{BBL}$ and $\mathrm{BHC}$ measurements were made by the midwives from labor wards or neonatal nurses in the infant area of the labor and delivery rooms within a time no longer than 2 to 2.5 hours following birth. The measurements were made after the "first contact" phase ended, where an infant spends some time lying on the mother's belly. All the measurements were performed during routine activities and were not recorded for the purpose of collecting data for the study. Due to a high number of neonates recorded every year (up to 5,000 in 2016) in the Maternity Department of the hospital, measurement of body size had been made by several employees.

The measurements of birth body weight were performed using RADWAG WPT 15D scales with an accuracy of \pm 5.0 grams, whereas a measuring tape was used to evaluate $\mathrm{BBL}$ and $\mathrm{BHC}$. Birth body length was evaluated based on the results of the measurement of crown-heel length performed on natural infant curvatures. Head circumference (occipitofrontal circumference) was measured according to clinical anthropology principles by means of a measuring tape located in a line passing through the frontal eminences (metopion anthropometric points between the frontal eminences) and the opisthocranion point located on the occipital bone or located over the superciliary arches and over the upper points that represent the connections of the skin of the auricles with the head skin of the neonate [21]. The results of birth size measurements were recorded in the standard medical documentation of individual children and input into the computer database of the center.

Duration of pregnancy, expressed in weeks, was determined by the doctors who were responsible for the pregnancy and was not further verified by the authors.

\section{Statistical analysis}

The data concerning body size and the duration and order of pregnancies were collected in an Excel database. The analyses were based only on the information concerning live births. The cohort was divided into classes according to the neonates' sex and duration of pregnancy. For each class, from 33 to 42 weeks of duration of pregnancy, mean values and standard deviations were calculated. Next, the ranges of broad population standard (from -2.0 to 2.0 SDS) were determined for individual characteristics, expressed in centimeters (BBL, BHC) and grams (BBW). Percentile values for the 10th and 90th centile in the cohort were also calculated 
for each body measurement. The strength of correlations between individual body measurements and duration of pregnancy were tested using the Pearson's test, with the level of significance set at $p<0.05$.

\section{RESULTS}

In 2011-2016, over 27,000 neonates were born from single pregnancies with the duration of pregnancy ranging from 33 to 42 weeks. Female neonates represented $48 \%$ ( $n=13163$ ) of the children. Table 1 illustrates the percentage of children born in individual weeks of pregnancy (starting from births in the $33^{\text {rd }}$ week) for all female neonates and all male neonates $(n=14118)$.

Tables 2 (for female neonates) and 3 (for male neonates) contain the means and values of one standard deviation from the means of BBL, BBW and BHC. Over a 6-year period of collecting the data, only a few cases $(n=3)$ were recorded for births from pregnancies of over 42 weeks. For this reason, this class was not presented with values of body size at birth. Due to a relatively insignificant number of cases, the study did not analyze the body measurements of neonates born from pregnancies with a duration shorter than 33 weeks ( $n=151$ : females: $n=71$; males: $n=80$ ).

It was demonstrated that regardless of sex, body measurements are positively and significantly correlated with duration of pregnancy, whereas BHC was significantly correlated with $\mathrm{BBL}$ and $\mathrm{BBW}$. Values of correlation coefficient $r$ are presented in Table 4.

Tables 5 to 10 present the values that determine the range of broad population standard (-2.0 SDS and 2.0 SDS) for each of the three body measurements. They are separately analyzed for female and male neonates.

Table 1. Number and percentage of female and male neonates born from pregnancies with durations ranging from 33 to 42 weeks

\begin{tabular}{|l|c|c|c|c|}
\hline \multirow{2}{*}{} & \multicolumn{2}{|c|}{ Female neonates } & \multicolumn{2}{c|}{ Male neonates } \\
\cline { 2 - 5 } & Number & Percentage & Number & Percentage $^{\mathrm{M}}$ \\
\hline Total & 13163 & $100 \%$ & 14118 & $100 \%$ \\
\hline 33 weeks & 60 & 0.46 & 59 & 0.42 \\
\hline 34 weeks & 93 & 0.71 & 113 & 0.80 \\
\hline 35 weeks & 205 & 1.56 & 215 & 1.52 \\
\hline 36 weeks & 349 & 2.65 & 511 & 3.62 \\
\hline 37 weeks & 845 & 6.42 & 930 & 6.59 \\
\hline 38 weeks & 2110 & 16.03 & 2376 & 16.83 \\
\hline 39 weeks & 3765 & 28.53 & 4033 & 28.57 \\
\hline 40 weeks & 3947 & 29.98 & 4042 & 28.63 \\
\hline 41 weeks & 1683 & 12.78 & 1730 & 12.25 \\
\hline 42 weeks & 115 & 0.87 & 109 & 0.77 \\
\hline
\end{tabular}

Notes: ${ }_{i} \mathrm{M}$ — female and male infants, respectively, related to all neonates
Table 2. Birth measurements (mean \pm SD) of female neonates versus duration of pregnancy

\begin{tabular}{|l|c|c|c|}
\hline & \multicolumn{3}{|c|}{ Female neonates } \\
\cline { 2 - 5 } & BBL $[\mathrm{cm}]$ & BBW $[\mathrm{g}]$ & BHC $[\mathrm{cm}]$ \\
\hline Total, $\mathrm{n}=13163$ & $3351.43 \pm 470.72$ & $54.22 \pm 2.83$ & $33.92 \pm 1.56$ \\
\hline 33 weeks & $1938.15 \pm 347.46$ & $45.55 \pm 2.97$ & $30.12 \pm 2.02$ \\
\hline 34 weeks & $2293.47 \pm 325.65$ & $48.39 \pm 2.65$ & $31.41 \pm 1.32$ \\
\hline 35 weeks & $2447.79 \pm 383.05$ & $49.55 \pm 2.70$ & $31.81 \pm 1.61$ \\
\hline 36 weeks & $2728.01 \pm 373.78$ & $51.20 \pm 2.62$ & $32.53 \pm 1.50$ \\
\hline 37 weeks & $2976.76 \pm 409.12$ & $52.44 \pm 2.57$ & $33.31 \pm 1.48$ \\
\hline 38 weeks & $3226.66 \pm 409.02$ & $53.63 \pm 2.50$ & $33.82 \pm 1.50$ \\
\hline 39 weeks & $3376.21 \pm 387.06$ & $54.36 \pm 2.43$ & $34.02 \pm 1.52$ \\
\hline 40 weeks & $3507.81 \pm 392.55$ & $54.97 \pm 2.53$ & $34.15 \pm 1.39$ \\
\hline 41 weeks & $3599.85 \pm 382.20$ & $55.48 \pm 2.41$ & $34.34 \pm 1.37$ \\
\hline 42 weeks & $3677.46 \pm 389.41$ & $56.02 \pm 2.21$ & $34.51 \pm 1.42$ \\
\hline
\end{tabular}

Table 3. Birth measurements (mean $\pm \mathrm{SD}$ ) of male neonates versus duration of pregnancy

\begin{tabular}{|l|c|c|c|}
\hline \multirow{2}{*}{ Total, $\mathrm{n}=14118$} & $3496.32 \pm 498.35$ & $54.95 \pm 2.97$ & $34.47 \pm 1.62$ \\
\hline 33 weeks & $2183.10 \pm 313.79$ & $47.61 \pm 2.70$ & $30.97 \pm 1.70$ \\
\hline 34 weeks & $2345.39 \pm 373.34$ & $48.83 \pm 2.74$ & $31.63 \pm 1.52$ \\
\hline 35 weeks & $2597.96 \pm 408.19$ & $50.34 \pm 2.95$ & $32.58 \pm 1.64$ \\
\hline 36 weeks & $2867.29 \pm 441.72$ & $51.54 \pm 2.85$ & $33.17 \pm 1.51$ \\
\hline 37 weeks & $3114.74 \pm 420.56$ & $53.13 \pm 2.50$ & $33.80 \pm 1.59$ \\
\hline 38 weeks & $3376.06 \pm 425.48$ & $54.40 \pm 2.60$ & $34.35 \pm 1.57$ \\
\hline 39 weeks & $3533.85 \pm 409.39$ & $55.11 \pm 2.58$ & $34.61 \pm 1.55$ \\
\hline 40 weeks & $3667.06 \pm 414.79$ & $55.81 \pm 2.59$ & $34.71 \pm 1.45$ \\
\hline 41 weeks & $3774.54 \pm 415.54$ & $56.48 \pm 2.56$ & $35.00 \pm 1.44$ \\
\hline 42 weeks & $3862.68 \pm 393.19$ & $56.50 \pm 3.01$ & $35.25 \pm 1.50$
\end{tabular}

\section{DISCUSSION}

Most neonates were born at full term, whereas preterm births accounted for less than $6 \%$ of the collected data ( $n=1605$, duration of the pregnancy $<37$ weeks). As mentioned before, the body measurements of children born before the $33^{\text {rd }}$ week and following the $42^{\text {nd }}$ week of pregnancy were not analyzed. It was observed that a similar number of girls and boys were born in the $33^{\text {rd }}$ and $42^{\text {nd }}$ week of gestation, whereas, more male births were recorded for other classes of duration of pregnancy. The phenomenon of sexual dimorphism was also confirmed as regardless of the duration of pregnancy, both mean values and those determining the ranges of broad population standards for $\mathrm{BBL}, \mathrm{BBW}$ and $\mathrm{BHC}$ were larger in boys compared to girls. It was found that regardless of the sex of neonates, $\mathrm{BHC}$ values were significantly correlated with BBL and BBW values (at $p<0.001$ for both 
Table 4. Strength of correlations between three body measurements and duration of pregnancy expressed by correlation coefficient

\begin{tabular}{|l|c|c|c|c|c|}
\hline & \multicolumn{3}{|c|}{ Duration of pregnancy to: } & \multicolumn{2}{c}{ BHC to: } \\
\cline { 2 - 6 } & BBW & BBL & BHC & BBW & BBL \\
\hline Female & $0.537^{* * *}$ & $0.458^{* * *}$ & $0,316^{* *}$ & $0.617^{* * *}$ & $0.486^{* * *}$ \\
\hline Male & $0.538^{* * *}$ & $0.470^{* * *}$ & $0.328^{* * *}$ & $0.634^{* * *}$ & $0.499^{* * *}$ \\
\hline
\end{tabular}

Notes: ** - statistically significant correlation coefficient of $0.01 ; * * *$ statistically significant correlation coefficient of 0.001

Table 5. Birth body length $(B B L[\mathrm{~cm}])$ of female neonates versus duration of pregnancy

\begin{tabular}{|c|c|c|c|c|c|}
\hline & \multicolumn{5}{|c|}{ Female neonates } \\
\hline & \multicolumn{2}{|c|}{ BBL $[\mathrm{cm}]$} & \multicolumn{3}{|c|}{ BBL $[\mathrm{cm}]$} \\
\hline & -2.0 SDS & 2.0 SDS & $10 \mathrm{ct}$ & $50 \mathrm{ct}$ & $90 \mathrm{ct}$ \\
\hline 33 weeks & 39.6 & 51.5 & 42.6 & 46.3 & 49.9 \\
\hline 34 weeks & 43.1 & 53.7 & 44.6 & 47.9 & 51.3 \\
\hline 35 weeks & 44.2 & 54.9 & 46.4 & 49.5 & 52.6 \\
\hline 36 weeks & 46.0 & 56.4 & 47.9 & 50.9 & 54.0 \\
\hline 37 weeks & 47.3 & 57.6 & 49.3 & 52.2 & 55.2 \\
\hline 38 weeks & 48.6 & 58.6 & 50.4 & 53.3 & 56.3 \\
\hline 39 weeks & 49.5 & 59.2 & 51.3 & 54.3 & 57.2 \\
\hline 40 weeks & 49.9 & 60.0 & 52.1 & 55.0 & 57.8 \\
\hline 41 weeks & 50.7 & 60.3 & 52.7 & 55.4 & 58.1 \\
\hline 42 weeks & 51.5 & 60.5 & 53.2 & 55.6 & 58.1 \\
\hline
\end{tabular}

Table 6. Birth body length (BBL $[\mathrm{cm}])$ of male neonates versus duration of pregnancy

\begin{tabular}{|c|c|c|c|c|c|}
\hline & & & le neon & & \\
\hline & & & & BBL $[\mathrm{cm}$ & \\
\hline & -2.0 SDS & $2.0 \mathrm{SDS}$ & $10 \mathrm{ct}$ & $50 \mathrm{ct}$ & $90 \mathrm{ct}$ \\
\hline 33 weeks & 42.2 & 53.0 & 43.5 & 47.3 & 51.1 \\
\hline 34 weeks & 43.3 & 54.3 & 45.2 & 48.8 & 52.4 \\
\hline 35 weeks & 44.4 & 56.2 & 46.8 & 50.3 & 53.8 \\
\hline 36 weeks & 45.8 & 57.2 & 48.3 & 51.7 & 55.0 \\
\hline 37 weeks & 48.1 & 58.1 & 49.6 & 52.9 & 56.3 \\
\hline 38 weeks & 49.2 & 59.6 & 50.8 & 54.1 & 57.4 \\
\hline 39 weeks & 50.0 & 60.3 & 51.7 & 55.0 & 58.4 \\
\hline 40 weeks & 50.6 & 61.0 & 52.4 & 55.8 & 59.2 \\
\hline 41 weeks & 51.4 & 61.6 & 52.7 & 56.2 & 59.7 \\
\hline 42 weeks & 50.5 & 62.5 & 52.7 & 56.4 & 60.0 \\
\hline
\end{tabular}

characteristics). As expected, it was also observed that regardless of the sex of neonates, both mean values and those used for determination of the boundaries of the broad population standards for BBL, BBW and BHC (from -2.0 SDS to 2.0 SDS) are greater for longer pregnancies.

A small number of previous Polish studies have simultaneously presented mean values for three body measurements, with relatively low numbers of study participants. The number of neonates in these groups ranged from 83 to 317 [22-24]. The researchers who presented the findings for these cohorts limited their measurements to birth body weight and/or birth body length, without recording birth head circumference [25-29]. With the number of neonates examined and evaluation of all three body measurements, this study is novel in Polish scientific literature. It should be emphasized that preparation of standards based on this 
Table 7. Birth body weight (BBW [g]) of female neonates versus duration of pregnancy

\begin{tabular}{|c|c|c|c|c|c|}
\hline & & & tale neor & & \\
\hline & & & & BBW [g] & \\
\hline & -2.0 SDS & $2.0 \mathrm{SDS}$ & $10 \mathrm{ct}$ & $50 \mathrm{ct}$ & $90 \mathrm{ct}$ \\
\hline 33 weeks & 1243.2 & 2633.1 & 1712.4 & 2000.8 & 2289.3 \\
\hline 34 weeks & 1642.2 & 2944.8 & 1959.7 & 2236.0 & 2512.2 \\
\hline 35 weeks & 1681.5 & 3213.9 & 2191.6 & 2483.1 & 2774.5 \\
\hline 36 weeks & 1980.5 & 3475.6 & 2425.1 & 2731.5 & 3038.0 \\
\hline 37 weeks & 2158.5 & 3795.0 & 2663.1 & 2970.8 & 3278.5 \\
\hline 38 weeks & 2408.6 & 4044.7 & 2898.1 & 3190.2 & 3482.3 \\
\hline 39 weeks & 2602.1 & 4150.3 & 3115.1 & 3379.1 & 3643.2 \\
\hline 40 weeks & 2722.7 & 4292.9 & 3294.7 & 3527.0 & 3759.3 \\
\hline 41 weeks & 2835.9 & 4364.4 & 3416.9 & 3623.2 & 3829.5 \\
\hline 42 weeks & 2889.3 & 4455.5 & 3463.9 & 3657.1 & 3850.3 \\
\hline
\end{tabular}

Table 8. Birth body weight (BBW [g]) of male neonates versus duration of pregnancy

\begin{tabular}{|c|c|c|c|c|c|}
\hline & \multicolumn{5}{|c|}{ Male neonates } \\
\hline & \multicolumn{2}{|c|}{ BBW [g] } & \multicolumn{3}{|c|}{ BBW [g] } \\
\hline & -2.0 SDS & $2.0 \mathrm{SDS}$ & $10 \mathrm{ct}$ & $50 \mathrm{ct}$ & $90 \mathrm{ct}$ \\
\hline 33 weeks & 1555.5 & 2810.7 & 1632.3 & 2094.6 & 2556.9 \\
\hline 34 weeks & 1598.7 & 3092.1 & 1878.7 & 2365.7 & 2852.6 \\
\hline 35 weeks & 1781.6 & 3414.3 & 2122.7 & 2631.2 & 3139.6 \\
\hline 36 weeks & 1983.8 & 3750.7 & 2359.5 & 2885.4 & 3411.4 \\
\hline 37 weeks & 2273.6 & 3955.9 & 2584.1 & 3122.8 & 3661.5 \\
\hline 38 weeks & 2525.1 & 4227.0 & 2791.8 & 3337.5 & 3883.3 \\
\hline 39 weeks & 2715.1 & 4352.6 & 2977.7 & 3523.9 & 4070.2 \\
\hline 40 weeks & 2837.5 & 4496.6 & 3136.9 & 3676.3 & 4215.7 \\
\hline 41 weeks & 2943.5 & 4605.6 & 3264.8 & 3789.0 & 4313.2 \\
\hline 42 weeks & 3076.3 & 4649.1 & 3356.3 & 3856.2 & 4356.1 \\
\hline
\end{tabular}

Table 9. Birth head circumference (BHC $[\mathrm{cm}])$ of female neonates versus duration of pregnancy

\begin{tabular}{|c|c|c|c|c|c|}
\hline & \multicolumn{5}{|c|}{ Female neonates } \\
\hline & \multicolumn{2}{|c|}{$\mathrm{BHC}[\mathrm{cm}]$} & \multicolumn{3}{|c|}{$\mathrm{BHC}[\mathrm{cm}]$} \\
\hline & -2.0 SDS & $2.0 \mathrm{SDS}$ & $10 \mathrm{ct}$ & $50 \mathrm{ct}$ & $90 \mathrm{ct}$ \\
\hline 33 weeks & 26.1 & 34.2 & 28.1 & 30.3 & 32.6 \\
\hline 34 weeks & 28.8 & 34.0 & 29.0 & 31.2 & 33.4 \\
\hline 35 weeks & 28.6 & 35.0 & 29.7 & 31.9 & 34.2 \\
\hline 36 weeks & 29.5 & 35.5 & 30.4 & 32.6 & 34.8 \\
\hline 37 weeks & 30.3 & 36.3 & 31.0 & 33.2 & 35.3 \\
\hline 38 weeks & 30.8 & 36.8 & 31.5 & 33.7 & 35.8 \\
\hline 39 weeks & 31.0 & 37.1 & 31.9 & 34.0 & 36.1 \\
\hline 40 weeks & 31.4 & 36.9 & 32.1 & 34.3 & 36.4 \\
\hline 41 weeks & 31.6 & 37.1 & 32.3 & 34.4 & 36.5 \\
\hline 42 weeks & 31.7 & 37.3 & 32.3 & 34.4 & 36.5 \\
\hline
\end{tabular}


Table 10. Birth head circumference (BHC [cm]) of male neonates versus duration of pregnancy

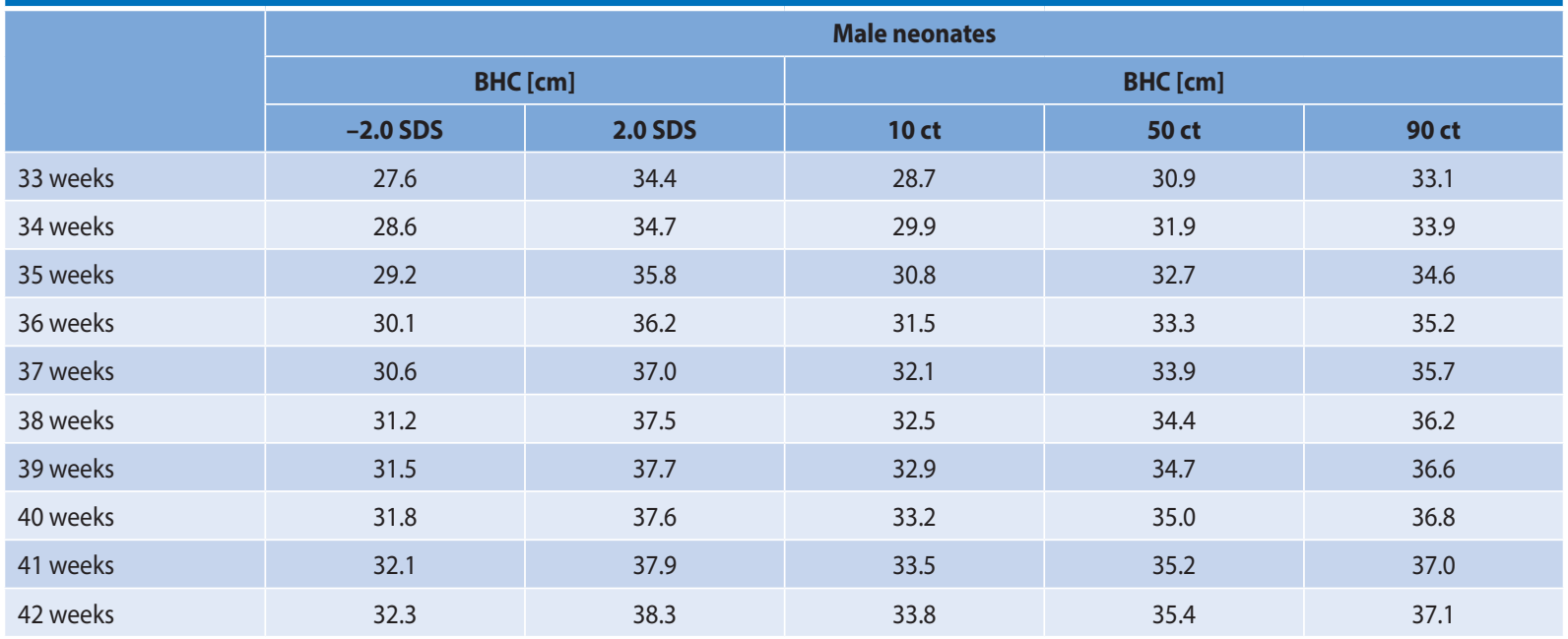

high number of measurements makes it possible to relate body measurements of neonates from the Masovia region to the standards presented by researchers from $\mathrm{WHO}$ and other European countries [18-20]. The mean values of body measurements of neonates born in a single center in 20112015 were compared with WHO standards and the standards developed previously in Poland, were recently (2017) published in Pediatria Polska [study available online since 30 May 2017; reference item No. 32]. For this reason, this study did not discuss the differences and similarities between individual standards of body size in neonates. It should be emphasized that the aim of the study was to determine the ranges of population values of $\mathrm{BBL}, \mathrm{BBW}$ and $\mathrm{BHW}$ in neonates from the Masovia region. Using the principles developed for anthropology, biometry and pediatrics, it was adopted that a "broad population standard" is the range from -2.0 SDS to 2.0 SDS for the specific characteristics. The values for the 10th and 90th percentile were also used since the percentile scale has been extensively used in clinical practice both in Poland and abroad [30]. However, in the case of neonates with a body size that is substantially smaller compared to population-based standards (BBL and/or BBW $<3^{\text {rd }}$ centile), the description of the degree of the deficit using the percentile scale is insufficient. Expressing the result of measurement with standard deviation units allows for an objective presentation of the degree of the deficit (or "excess") compared to the population-based standards. This procedure allows for the differentiation between neonates with moderate deficits of BBL and/or BBW (ranging from -2.0 to 2.5 SDS) and those with profound growth restriction (BBL and/or BBW $<-2.5 \mathrm{SDS}$ ). If any of the body measurements of a neonate falls outside the range of the population standard, it is recommended to routinely differentiate the causes of the growth restriction with the best procedures conducted by means of uniform principles (procedure algorithms for deficits of body me- asurements at birth) [31]. As often presented in literature, the insufficient development of body size with respect to duration and course of pregnancy can be diagnosed by fetal growth imaging (Intrauterine Growth Retardation, Intrauterine Growth Restriction, Fetal Growth Restriction, IUGR) or by means of birth body measurements (Small for Gestational Age, SGA). As mentioned above, deficits of birth body size can reflect the elevated risk of disturbed growth, which in a number of children requires the implementation of treatment with growth hormones [32]. It was also demonstrated that in certain neonates born with body size deficits, the risk of disturbances in glucose tolerance and insulin resistance is elevated [33, 34]. The phenomenon of body size deficits at birth in infants with certain genetic conditions, such as Turner syndrome, has also been described ( 1 per 2,500 births of female neonates, with at least several dozen children born with the syndrome every year in Poland) [35].

\section{CONCLUSIONS}

The above clinical facts were found to be important arguments for body measurements as a reference to the updated standards presented in this study. The importance of implementation of the programs for monitoring of growth of children born with insufficient body size with respect to the duration of pregnancy has been emphasized in literature for many years [34, 35]. Such protocols are routinely used to verify whether one of the body measurements of the child is not lower than the boundary value for the broad population standards. In such cases, the use of standards developed based on the sufficiently high number of measurements conducted in a similar manner is crucial. Since the standards presented in the study meet the above criterion, they can be successfully used in clinical practice with particular focus on routine screening used for detecting cases of neonates born with body size deficits. 


\section{REFERENCES}

1. Holt LE. Holt Diseases of Infancy and Childhood, Holt-Mclntosh's Textbook of Pediatrics, New York-Presbyterian Morgan Stanley Children's Hospital. ; 1896.

2. Ylppö A. New classification and nomenclature for newborn infants including prematures and abortions. Acta Paediatr. 1948; 35(Suppl 1): 160-163, indexed in Pubmed: 18885521.

3. Barker DJP, Osmond C. Infant mortality, childhood nutrition and ischaemic heart disease in England and Wales. Lancet. 1986; 327(1): 1077-1081.

4. Barker DJP, Osmond C, Winter PD, et al. Weight in infancy and death from ischemic heart disease. Lancet. 1989; 334(2): 577-580.

5. Hales CN, Barker DJP, Clark PM, et al. Fetal and infant growth and impaired glucose tolerance at age 64. BMJ. 1991; 303(6809): 1019-1022.

6. David JP. Barker DJP, Gelow J, Thornburg K, Osmond C, Kajantie E, Eriksson JG. The early origins of chronic heart failure: impaired placental growth and initiation of insulin resistance in childhood. Eur J Heart Fail. 2010; 12(8): 819-825.

7. Seremak-Mrozikiewicz A, Barlik M, Drews K. Programowanie wewnątrzmaciczne jako przyczyna chorób przewlekłych wieku dorosłego. Ginekol Pol. 2014; 85(1): 43-48.

8. Boguszewski M, Rosberg S, Albertsson-Wikland K. Spontaneous 24hour growth hormone profiles in prepubertal small for gestational age children. J Clin Endocrinol Metab. 1995; 80(9): 2599-2606, doi: 10.1210/jcem.80.9.7673401, indexed in Pubmed: 7673401.

9. Boguszewski M, Jansson C, Rosberg S, et al. Changes in serum insulin-like growth factor I (IGF-I) and IGF-binding protein-3 levels during growth hormone treatment in prepubertal short children born small for gestational age. J Clin Endocrinol Metab. 1996; 81(11): 3902-3908, doi: 10.1210/jcem.81.11.8923836, indexed in Pubmed: 8923836.

10. Karlberg J, Albertsson-Wikland K. Growth in full-term small-for-gestational-age infants: from birth to final height. Pediatr Res. 1995; 38(5): 733-739, doi: 10.1203/00006450-199511000-00017, indexed in Pubmed: 8552442.

11. Boguszewski M, Albertsson-Wikland K, Aronsson S, et al. Growth hormone treatment of short children born small-for-gestational-age: the Nordic Multicentre Trial. Acta Paediatr. 1998; 87(3): 257-263, indexed in Pubmed: 9560030.

12. Haymond $M$, Kappelgaard $A M$, Czernichow $P$, et al. Early recognition of growth abnormalities permitting early intervention. Acta Paediatr. 2013; 102(8): 787-796.

13. Gardosi J. Customised assessment of fetal growth potential: implications for perinatal care. Arch Dis Child: Fetal Neonatal Ed. 2012; 97(5): F314-317.

14. Eide MG, Oyen N, Skjaerven $R$, et al. Size at birth and gestational age as predictors of adult height and weight. Epidemiology. 2005; 16(2): 175-181.

15. Gibson AT, Carney S, Wright NP, et al. Measurement and the newborn infant. Horm Res. 2003; 59(suppl. 1): 119-128.

16. Giuliani F, Ohuma E, Spada E, et al. Systematic review of the methodological quality of studies designed to create neonatal anthropometric charts. Acta Paediatr. 2015; 104(10): 987-996, doi: 10.1111/apa.13112, indexed in Pubmed: 26154879.

17. de Onis M, Onyango AW, Van den Broeck J, et al. Measurement and standardization protocols for anthropometry used in the construction of a new international growth reference. Food Nutr Bull. 2004; 25(1 Suppl): S27-S36, doi: 10.1177/15648265040251S104, indexed in Pubmed: 15069917.
18. WHO: http://www.who.int/childgrowth/standards/weight_for_height/en/. (12.07.2017)

19. Ziegler EE, Nelson SE. The WHO growth standards: strengths and limitations. Curr Opin Clin Nutr Metab Care. 2012; 15(3): 298-302, doi: 10.1097/MCO.0b013e3283511478, indexed in Pubmed: 22327335.

20. Christesen HT, Pedersen BT, Pournara E, et al. Short Stature: Comparison of WHO and National Growth Standards/References for Height. PLoS One. 2016; 11(6): e0157277.

21. Wolański N, Wolański N. Organizacja i przeprowadzenie badań kontrolnych. Metody kontroli i normy rozwoju dzieci i młodzieży, PZWL, Warszawa 1975, 98-106, 232

22. Krajewska A, Kuliś K, Krajewska A, et al. Kondycja biologiczna noworodków z Kędzierzyna-Koźla urodzonych w 2004 roku. Nowa Pediatr. 2006; 1: 16-21.

23. Zatorska M, Zatorska M. Evaluation of acceleration of somatic development of Lublin newborns over the period of twenty years. Stud Hum Ecol. 1992; 10: 83-93, indexed in Pubmed: 1344737.

24. Rosset I, Rosset I. Rozkłady centylowe wielkości urodzeniowych noworodków łódzkich urodzonych w terminie. Ped Pol. 2009; 84: 151-158.

25. Malewski Z, Słomko Z, Uklejewski A, et al. Relationship between gestational age and birth weight in Wielkopolska region. Klin Perinat Gin. 1995; 2: 734-741.

26. Gadzinowski J, Kaliszewska-Drozdowska MD, Kosińska M, et al. Urodzeniowa masa ciała a wiek płodowy noworodków regionu Wielkopolski i Ziemi Lubuskiej. Gin Pol. 2003; 74(3): 186-192.

27. Kurniewicz-Witczakowa R, Miesowicz I, Niedźwiecka Z, et al. Siatki centylowe wysokości, masy ciała oraz grubości fałdów skórno-tłuszczowych dzieci i młodzieży warszawskiej od urodzenia do 18 roku życia. Probl Med Wieku Rozw. 1983; 12: 56-67.

28. Kaliszewska-Drozdowska MD, Kaliszewska-Drozdowska MD. Noworodek - stan rozwoju fizycznego i trendy rozwojowe urodzeniowej masy ciała. Przegl Antrop. 1992; 55 (1-2. : 33-43.

29. Wiśniewski A, Pawlus B, Milde K, et al. Body measurements of neonates born at one centre in the administrative region of Masovia in the years 2011-2015. Ped Pol. 2017; available online 30 May 2017.

30. Vayssière $C$, Sentilhes $L$, Ego $A$, et al. Fetal growth restriction and intra-uterine growth restriction: guidelines for clinical practice from the French College of Gynaecologists and Obstetricians. Eur J Obstet Gynecol Reprod Biol. 2015; 193: 10-18.

31. Villar J, Papageorghiou AT, Pang R, et al. Monitoring human growth and development: a continuum from the womb to the classroom. Am J Obstet Gynecol. 2015;213(4): 494-499, doi: 10.1016/j.ajog.2015.07.002, indexed in Pubmed: 26184778.

32. Hwang IIT. Efficacy and safety of growth hormone treatment for children born small for gestational age. Korean J Pediatr. 2014; 57(9): 379-383, doi: 10.3345/kjp.2014.57.9.379, indexed in Pubmed: 25324863.

33. Monier I, Blondel B, Ego A, et al. Does the presence of risk factors for fetal growth restriction increase the probability of antenatal detection? A French National Study. Paediatr Perinat Epidemiol. 2016; 30(1): 46-55.

34. Eriksson JG. Early growth and coronary heart disease and type 2 diabetes: findings from the Helsinki Birth Cohort Study (HBCS). Am J Clin Nutr. 2011; 94(6 suppl): 1799S-1802S.

35. Wiśniewski A, Milde K, Stupnicki R. Fetal dystrophy-one of the feature of Turner syndrome. Endokrynol Diabetol. 2005; 11(3): 177-180. 